\title{
The Distribution of a Peptide Neurotransmitter in the Postembryonic Grasshopper Central Nervous System ${ }^{1}$
}

\author{
HAIG KESHISHIAN ${ }^{2}$ AND MICHAEL O'SHEA \\ Committee on Neurobiology, The University of Chicago, Chicago, Illinois 60637
}

\begin{abstract}
Proctolin is a peptide neurotransmitter, discovered in the visceral muscles of the cockroach. The peptide has recently been identified in the nervous systems of many invertebrates. Using reverse phase high pressure liquid chromatography together with a sensitive bioassay, we analyzed the distribution of proctolin in the central nervous system of the grasshopper Schistocerca nitens. We also used immunocytochemistry to identify about $\mathbf{7 0}$ diverse proctolin-staining neurons in the postembryonic ventral nerve cord. Proctolin immunoreactivity is rare, being found in only about $0.6 \%$ of the ganglionic neurons. Among the cells we stained for proctolin were thoracic skeletal motoneurons, a cluster of efferents to the intrinsic muscles of the hindgut, and both inter- and intraganglionic thoracic interneurons, as well as several interspecies homologues to proctolin-staining neurons in the cockroach. The map of proctolin expression within the central nervous system is not extensively altered during postembryonic life. It is the product of embryonic development, which is the subject of the following paper (Keshishian, H., and M. O'Shea (1985) J. Neurosci. 5: 1005-1015).
\end{abstract}

Proctolin (Arg-Tyr-Leu-Pro-Thr) is a neuropeptide that was discovered in the cockroach Periplaneta americana and was proposed as the neurotransmitter substance of insect visceral muscle (Brown, 1967; Brown, 1975; Brown and Starratt, 1975; Starratt and Brown 1975; Holman and Cook, 1979). Proctolin has since been shown to be widely distributed in insects (Brown, 1977) and other arthropods (Sullivan, 1977; Bishop et al., 1984; Schwarz et al., 1984). O'Shea and Adams (1981) first identified specific central neurons containing proctolin, and the distribution of proctolin-staining neurons of the cockroach CNS has been described (Bishop and O'Shea, 1982a). Proctolin is present in uniquely identifiable insect skeletal motoneurons (O'Shea and Bishop, 1982), and it is also found in the postural motoneurons of the crayfish (Bishop et al., 1984). These observations suggest that, in addition to acting as a visceral transmitter, proctolin may also be a skeletal neuromuscular transmitter. Adams and O'Shea (1983) confirmed this hypothesis by showing that proctolin acts as a cotransmitter at the neuromuscular junction of an identified skeletal motoneuron in the cockroach.

Received May 29, 1984; Revised November 6, 1984;

Accepted November 9, 1984

${ }^{1}$ We thank Jane Witten and Mary Kate Worden for advice and for criticism of the manuscript. The work is supported by National Institutes of Health Grant NS06864-01 (H. K.) and National Science Foundation Grant BNS 8202515 (M. O.).

${ }^{2}$ To whom correspondence should be sent, at: Department of Biology, Yale University, Box 6666, Kline Tower, New Haven, CT 06511.
In addition to its role as a neuromuscular transmitter, proctolin may also function as a neurohormone. Thus, it is found in abundance in and is released from the neurosecretory pericardial organs of the lobster (Schwarz et al., 1984). Its neurohormonal role in crustaceans is also indicated by its actions on cardiac muscle (Sullivan, 1979; Miller and Sullivan, 1981), stomatogastric muscle (Lingle, 1979), and skeletal muscles that are not known to be directly innervated by proctolin-containing neurons (Kravitz et al., 1980; Schwarz et al., 1980).

Using high pressure liquid chromatography (HPLC), a sensitive bioassay, and immunohistochemistry, we establish here the presence of proctolin and describe its regional and cellular distribution in the grasshopper Schistocera nitens. We have uniquely identified the cell body locations of more than 70 proctolin-staining neurons in the ventral nerve cord of the postembryonic grasshopper. We have also described the morphology and postsynaptic targets of several identified putatively proctolinergic neurons (see also Keshishian and O'Shea, 1985). A few of these cells are interneurons, representing the first observation of uniquely identified proctolin-staining cells with targets exclusively within the CNS.

Grasshoppers are highly favorable organisms for the study of both the cellular basis of behavior (Pearson and O'Shea, 1985) and the embryonic development of uniquely identifiable neurons (Goodman et al., 1984; Bentley and Keshishian, 1982). We hope, therefore, that our description will act as a guide for further studies of peptidergic mechanisms in behavior and of the developmental mechanisms of neurotransmitter selection in identified cells.

\section{Materials and Methods}

Nerve cords and other tissues were obtained from our colony of the grasshopper Schistocerca nitens, maintained at the University of Chicago.

\section{Immunocytochemistry}

About $30 \%$ of the animals examined in this study were injected with colchicine, a technique found in $P$. americana to improve immunocytochem ical staining (Bishop and O'Shea, 1982a). We did not observe substantial improvements in immunocytochemical staining for adult material using this method. Adult staining was uniformly poor, with only occasionally usable ganglia. In the preadult stages colchicine pretreatment gave staining that was no better than that seen in controls. However, we did observe substantial improvements in staining following desheathing, especially in the later instars.

Ventral nerve cords were dissected in isotonic physiological saline (140 $\mathrm{mm} \mathrm{NaCl}, 5 \mathrm{~mm} \mathrm{KCl}, 5 \mathrm{~mm} \mathrm{CaCl}_{2}, 1 \mathrm{~mm} \mathrm{MgCl}, 4 \mathrm{~mm} \mathrm{NaHCO}, 5 \mathrm{~mm}$ TES, $5 \mathrm{~mm}$ trehalose, $100 \mathrm{~mm}$ sucrose, $\mathrm{pH} 7.2$ ). The nerve cords were fixed overnight at $4^{\circ} \mathrm{C}$ in $4 \%$ paraformaldehyde with $50 \mathrm{~mm}$ sodium phosphate buffer, $\mathrm{pH}$ 7.3. Fixed nerve cords were rinsed and agitated for $1 \mathrm{hr}$ in buffered medium with Triton $X-100$ added $\left(20 \mathrm{mM} \mathrm{NaH}_{2} \mathrm{PO}_{4}, 150 \mathrm{~mm} \mathrm{NaCl}, 0.3 \%\right.$ Triton X-100, pH 7.3). All solutions were prepared in this medium, and all incubations were performed at $4^{\circ} \mathrm{C}$ with agitation, except where indicated. Washed nerve cords were incubated in $10 \%$ normal goat serum (NGS) for $1 \mathrm{hr}$, followed by $48 \mathrm{hr}$ in the primary proctolin-specific antiserum (serum 9 , $1: 800$ in 1\% NGS; Bishop et al., 1981).

For whole mount peroxidase-antiperoxidase (PAP) staining we followed the methods outlined in Bishop and O'Shea (1982a). Nerve cords were also 
prepared for fluorescence immunocytochemistry: following incubation with the primary antiserum (using the protocol described above), the nerve cords were washed for $1 \mathrm{hr}$ and incubated for $2 \mathrm{hr}$ in 1:500 fluorescein isothiocyanate (FITC)- or tetramethylrhodamine isothiocyanate (TRITC)-labeled goat anti-rabbit lgG, in $10 \%$ NGS. Following a wash for 1 to $2 \mathrm{hr}$, the whole tissue was mounted in 5\% n-propyl gallate in glycerol, $\mathrm{pH} 7.3$ (Giloh and Sedat, 1982), and observed with an epi-illumination fluorescence microscope.

The attinity of antiserum 9 to proctolin has been measured by radioimmunoassay (Bishop et al., 1981), and the histological specificity of this antiserum was demonstrated in the cockroach P. americana (Bishop and O'Shea, 1982a). When we incubate the primary antiserum with $1.5 \mu \mathrm{mol} / \mathrm{ml}$ of authentic proctolin overnight at $4^{\circ} \mathrm{C}$, all specific staining is prevented. We have used the terms "proctolin staining" and "proctolin-like immunoreactive" in the text for neurons that are demonstrated with this serum.

\section{Determination of proctolin levels}

For this study and the following one (Keshishian and O'Shea, 1985) we developed a direct quantitative assay for proctolin at the levels found in ganglia and embryonic tissue by combining a biological assay with reverse phase HPLC. The dose-response curve of the bioassay extends over at least two decades of proctolin concentration, and is approximately 50 -fold more sensitive than our proctolin radioimmunoassay (Bishop et al., 1981).

Peptide purification. To extract peptides, tissues were homogenized in $500 \mu$ l of cold methanol:water:glacial acetic acid (90:9:1). The crude homogenates were centrifuged for $5 \mathrm{~min}$ and the supernatant was collected. Pellets were resuspended in an additional $500 \mu$ of the homogenizing fluid and centrifuged again. The combined supernatants were dried under reduced pressure at $60^{\circ} \mathrm{C}$. Each dried supernatant was dissolved in $1 \mathrm{ml}$ of distilled water prior to the first chromatographic procedure using a Waters $C_{18}$ SepPak cartridge. These cartridges trap hydrophobic molecules from large aqueous volumes on the $C_{18}$ packing, which can then be eluted with a smal volume of methanol. This allows for a convenient desalting and initial purification of the crude extracts. After loading a cartridge with a dissolved supernatant, it was first flushed with $5 \mathrm{ml}$ of $\mathrm{dH}_{2} \mathrm{O}$ followed by $5 \mathrm{ml}$ of $15 \%$ methanol in $\mathrm{dH}_{2} \mathrm{O}$, and the eluates were discarded. Three milliliters of $100 \%$ methanol were passed through the cartridge, collected, and dried under reduced pressure at $60^{\circ} \mathrm{C}$. We previously determined that tritiated proctolin added to tissue samples is completely recovered in this fraction.

In some experiments, the Sep-Pak-purified material was assayed for proctolin-like bioactivity (PLB) after dissolving it in physiological saline (see below for details of the bioassay). In other experiments we further purified Sep-Pak-processed material by reverse phase HPLC and bioassayed the fractions that coelute with authentic proctolin. In this way we found that the PLB of Sep-Pak-processed material is exclusively due to the peptide proctolin (see "Results" for details).

For reverse phase HPLC the dried Sep-Pak-processed material was dissolved in up to $100 \mu \mathrm{l}$ of $5 \%$ acetonitrile in $50 \mathrm{~mm}$ ammonium acetate, $\mathrm{pH}$ 4.5 , and injected onto an analytical $C_{18}$ column $(10 \mu \mathrm{m}) \mu$ BondaPak, Waters Associates). The sample was chromatographed with a linear concentration gradient of 5 to $50 \%$ acetonitrile mixed with $50 \mathrm{~mm}$ ammonium acetate $(\mathrm{pH}$ 4.5 in $\mathrm{H}_{2} \mathrm{O}$ ) at $1 \mathrm{ml} / \mathrm{min}$. The efflux from the column was fractionated by an automatic collector at 50-drop $(\sim 1 \mathrm{ml})$ fractions. Under these conditions authentic tritiated proctolin (New England Nuclear, Boston, MA) is recovered in fraction 18 (see Fig. 1). In some experiments the peptide was chromatographed isocratically using $12.5 \%$ acetonitrile in $50 \mathrm{~mm}$ ammonium acetate, $\mathrm{pH}$ 4.5. In order to control for possible column- or injection system-derived contamination, we preceded each experimental chromatograph with an injection of $100 \mu \mathrm{l}$ of the buffer. This was chromatographed, collected, and assayed for PLB. Each experimental chromatograph was also followed by the chromatography of a tritiated standard of proctolin. To determine the efficiency of extraction and recovery, we added tritiated proctolin to some homogenates.

Bioassay of proctolin. Samples were bioassayed by applying $1-\mu$ laliquots to the myogenically active extensor tibiae muscle bundle of the adult grasshopper metathoracic leg (refer to Fig. 3 of Evans and O'Shea, 1978). This muscle generates a rhythmic oscillation of the tibia, the frequency of which is increased by proctolin. A small flap of cuticle was opened to provide direct access to the proctolin-sensitive muscle fibers. A small paper flag was attached to the tibia, and its unhindered motion was monitored photoelectrically by the interruption of a light path. The transduced signal was digitized and analyzed by a computer during the experiment.

We find that the log of the peak frequency achieved following the application of proctolin is linearly related to the log of the concentration over about two decades (see Fig. $1 A$.). We have exploited this relation to generate standard dose-response curves for quantifying the proctolin equivalence in our samples.

\section{Results}

\section{Presence of proctolin and its regional distribution in the CNS}

We have established the presence of the neuropeptide proctolin in the grasshopper Schistocerca nitens by combining HPLC fractionation with a bioassay. Using HPLC, we purified and recovered the proctolin present in tissue. The bioassay was then used to quantify the amount of proctolin in our samples.

Figure $1 A$ illustrates the relationship obtained between the peak oscillation frequency of the extensor tibiae muscle and the mass in moles of applied proctolin. Three examples of the muscle's response to the applied proctolin are illustrated in the dose-response curve (Fig. $1 A$ ), corresponding to the three molar amounts on the curve below the arrows. The arrows also indicate the time when $1-\mu \mid$
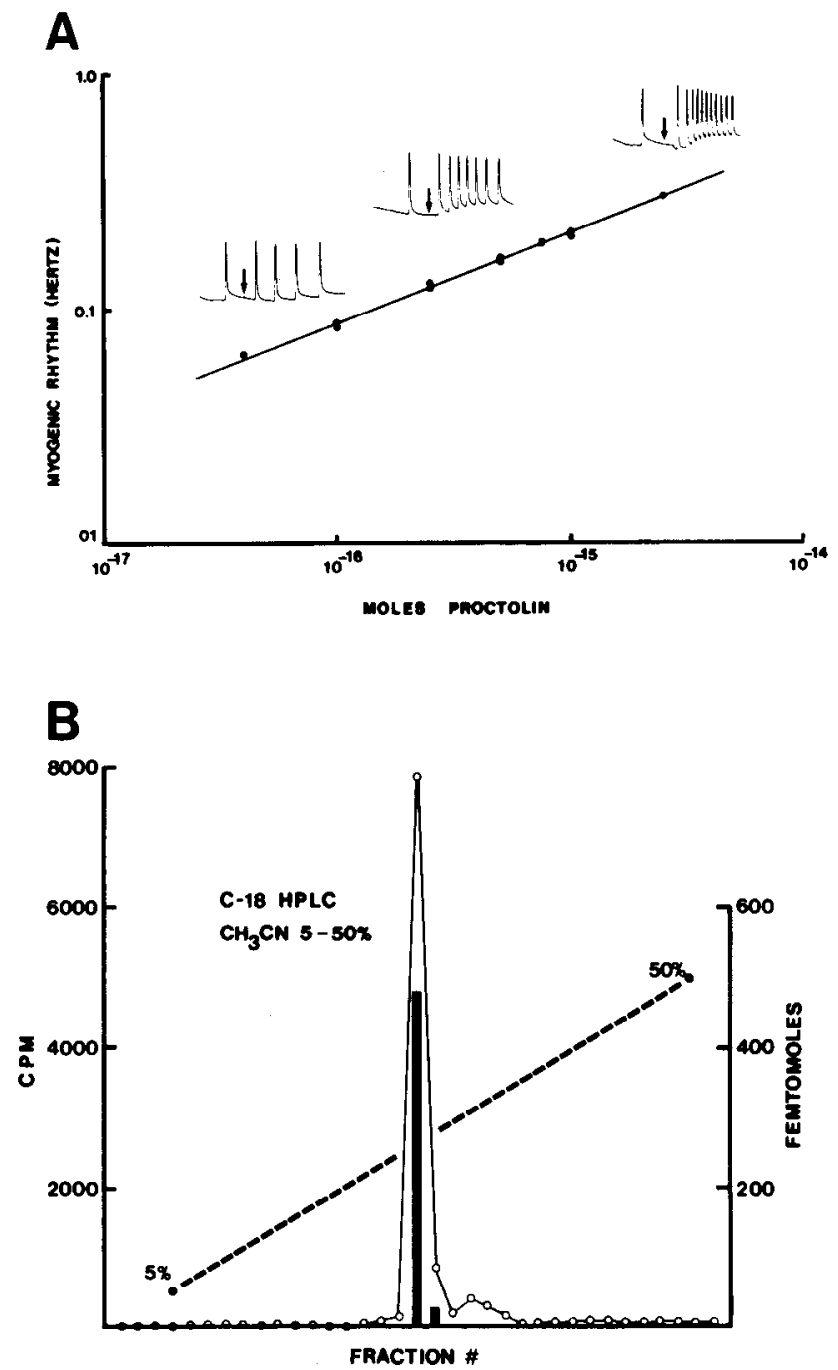

Figure 1. A, A sample dose-response curve relating the peak frequency (in hertz) of the myogenic rhythm of the extensor tibiae muscle to locally applied proctolin. One-microliter concentration standards in saline were applied to the surface of the active muscle bundle, with the frequency response monitored optically (three examples shown above the curve, see "Results"). The amount of proctolin in tissue samples was estimated from standard curves such as this one. B, PLB is due exclusively to proctolin. Homogenates of hatchlings were chromatographed by reverse phase acetonitrile gradient HPLC (dashed line), with successive 50-drop (about 1 min) fractions bioassayed. All of the PLB (solid bars, scale on right) was contained in the fractions that co-migrate with the radioactivity of a tritiated proctolin standard (open circles, scale on left). 


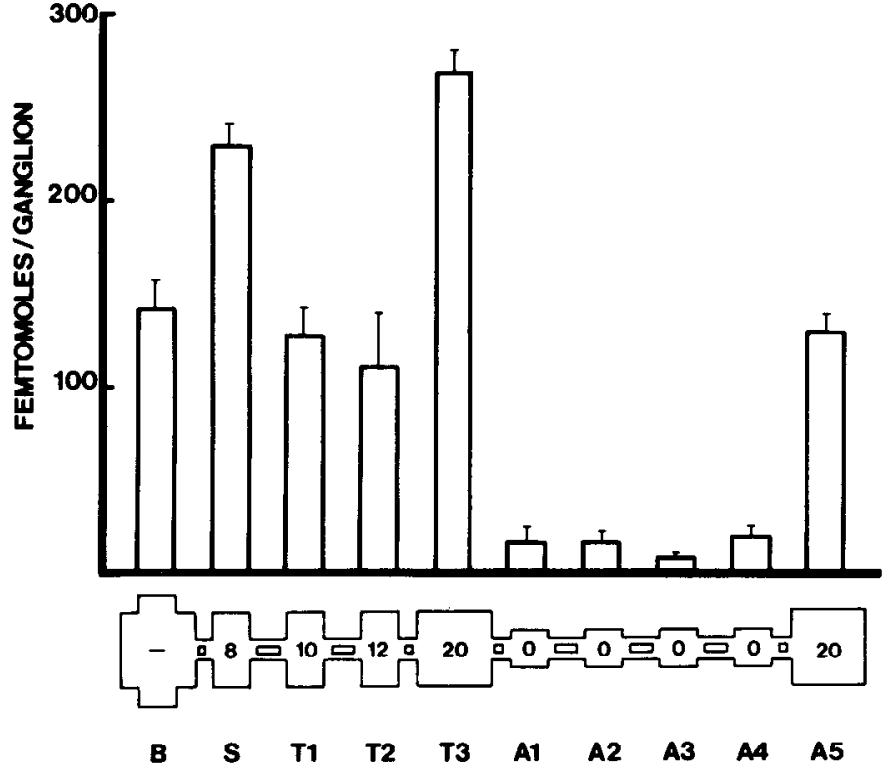

Figure 2. The regional ganglionic distribution of proctolin in the adult CNS. Under the histogram is a diagram of the CNS with the number of proctolinimmunoreactive neurons described in this study. $B$, brain; $S$, subesophageal ganglion; $T 1$ to $T 3$, thoracic ganglia 1 to 3 ; $A 1$ to $A 5$, abdominal ganglia 1 to 5 . Error bars $=1 \mathrm{SD}$ of the mean $(n=5)$.

TABLE I

Neurons with somatic PLI described in this study

\begin{tabular}{|c|c|c|c|c|}
\hline Ganglion & Number $^{a}$ & Cells & Comments & Size $^{b}$ \\
\hline $\begin{array}{l}\text { Subesophageal } \\
(228 \pm 2)^{c}\end{array}$ & $\begin{array}{l}6 S \\
2 S\end{array}$ & $\begin{array}{l}\text { AM } \\
\text { VM }\end{array}$ & Project to brain & $\begin{array}{l}15-35 \\
15\end{array}$ \\
\hline $\begin{array}{l}\text { Prothoracic } \\
(126 \pm 3)\end{array}$ & $\begin{array}{l}2 S \\
2 M \\
6 S \cdot M\end{array}$ & $\begin{array}{l}\text { VM } \\
\text { AVL } \\
\text { PDL }\end{array}$ & $\begin{array}{l}\text { Putative interneuron } \\
\text { Putative efferents } \\
\text { Often stain with } \\
\text { other faint vari- } \\
\text { able cells }\end{array}$ & $\begin{array}{l}10-15 \\
15 \\
15\end{array}$ \\
\hline $\begin{array}{l}\text { Mesothoracic } \\
(112 \pm 6)\end{array}$ & $\begin{array}{l}2 S \\
6 M \\
4 M\end{array}$ & $\begin{array}{l}\text { VM } \\
\text { AVL } \\
\text { PDL }\end{array}$ & $\begin{array}{l}\text { Putative interneuron } \\
\text { Putative efferents }\end{array}$ & $\begin{array}{l}10-15 \\
15 \\
15\end{array}$ \\
\hline \multirow[t]{4}{*}{$(267 \pm 2)$} & $\begin{array}{l}2 S \\
2 S \\
2 M\end{array}$ & $\begin{array}{l}V M \\
V M \\
V M\end{array}$ & $\begin{array}{l}\text { Anterior interneuron } \\
\text { Posterior interneuron } \\
\text { In 3rd abdom. seg. } \\
\text { ment }\end{array}$ & $\begin{array}{l}15-25 \\
15-25 \\
15\end{array}$ \\
\hline & $6-10 \mathrm{~S}$ & AVL & $\begin{array}{l}\text { Putative motoneu- } \\
\text { rons that may in- } \\
\text { clude SETi }\end{array}$ & $15-25$ \\
\hline & $2 \mathrm{~s}$ & PDL & $\begin{array}{l}\text { Occur in same rela- } \\
\text { tive position as } \\
\text { the cockroach Ds } \\
\text { cells }\end{array}$ & $20-25$ \\
\hline & $2 M$ & PDL & & 20 \\
\hline $\begin{array}{l}\text { Terminal } \\
(127 \pm 4)\end{array}$ & $\begin{array}{r}6 \mathrm{~S} \\
14-16 \mathrm{M}\end{array}$ & $\begin{array}{l}\text { AM } \\
\text { PM }\end{array}$ & $\begin{array}{l}\text { Efferent cluster }^{d} \\
\text { First appear within } \\
24 \mathrm{hr} \text { after hatch- } \\
\text { ing }\end{array}$ & $\begin{array}{l}25-40 \\
15-25\end{array}$ \\
\hline
\end{tabular}

${ }^{a}$ Total number of ganglionic somata. S, strong PLI; M, moderate PLI.

${ }^{D}$ Cell body diameter, first instar, range in micrometers.

${ }^{c}$ Numbers in parentheses, adult proctolin contents in femtomoles \pm SEM.

${ }^{\sigma} 50 \%$ of sample $=6$ ventral; $25 \%=5$ ventral, 1 dorsal; $25 \%=4$ ventral, 2 dorsal. aliquots of standard proctolin concentrations were applied. This figure is typical of standard curves used to quantify levels of proctolin in both Sep-Pak- and HPLC-purified tissue. Standard curves were useful for estimating proctolin levels over the two-decade range from $5 \times 10^{-17}$ to $5 \times 10^{-15} \mathrm{~mol}$. The linear regression line drawn from the data typically had a correlation coefficient $(r)$ value above +0.96 ( $n>25$ curves) for these $\log / \log$ representations.

Figure $1 B$ presents the HPLC evidence for the presence of proctolin in the grasshopper. Whole animals (newly hatched) were homogenized, processed on Sep-Pak $\mathrm{C}_{18}$ cartridges, and chromatographed in reverse phase on a $\mathrm{C}_{18}$ column with a linear acetonitrile gradient (5 to $50 \%$ ). Each fraction was recovered and bioassayed, and the PLB was converted to its molar equivalent of proctolin using a standard curve. The fraction into which proctolin elutes was determined by chromatographing under identical conditions a tritiated proctolin standard. The figure shows that all measurable PLB eluted by this gradient exactly co-migrates with proctolin. The mean level of proctolin per animal, approximately $450 \mathrm{fmol}(n=5)$, is found in the peak fraction. The fact that no other bioactive peaks were detected suggests that the PLB present in the partially purified (Sep-Pak treated) extract is due predominantly to proctolin. By directly measuring the Sep-Pak and HPLC levels of PLB, we have confirmed this at several stages of development (Keshishian and O'Shea, 1985).

Using Sep-Pak-purified extracts and bioassay, we have surveyed the regional distribution of proctolin in the CNS (Fig. 2). Three adult female nerve cords were dissected, and the ganglia were isolated and pooled, extracted, and bioassayed. The data represent the averages $\pm S D$ of the determinations made in five separate pools of ganglia.

The adult CNS contains the equivalent of $1.1 \mathrm{pmol}$ of proctolin. There is an unequal ganglionic distribution of the neuropeptide. The highest levels are found in the compound metathoracic ganglion (267 $\pm 9 \mathrm{fmol})$, followed by the subesophageal ganglion (228 \pm 11$)$ and brain (142 \pm 16$)$. Roughly equal levels of proctolin were recovered from the prothoracic $(125 \pm 13)$, mesothoracic $(112 \pm$ 29), and terminal ganglia (127 \pm 19 ). The remaining four free abdominal ganglia possess the lowest levels (ranging from 11 to 22 fmol). Beneath the histogram is a diagram of the CNS, showing the number of proctolin-immunoreactive neurons present in the indicated ganglion and described in this study. The levels of proctolin are well correlatcd with these numbers. This suggests that the cells stained with our antibody (see below) contain the proctolin we measure here.

\section{Proctolin immunocytochemistry}

Consistent and intense proctolin staining was obtained in the preadult stages of Schistocerca. As we wished to describe an endpoint for the embryonic expression of the neuropeptide, the description in this study is taken from hatchlings. We have also compared this pattern of proctolin staining to that found at later stages of development. We find that the pattern found in the first instar is not significantly altered during the preadult postembryonic stages. In adults, for reasons we cannot explain, staining was capricious. These results were observed despite the preinjection of colchicine in about $30 \%$ of the animals. Colchicine has been found to improve whole mount immunocytochemistry in P. americana (Bishop and O'Shea, 1982a). We found that desheathing ganglia prior to staining was of value, especially in the later instars.

The following description of immunoreactivity was obtained from about 80 nerve cords immediately before hatching (100\% stage of embryogenesis) and about 40 nerve cords from first instar nymphs up to $48 \mathrm{hr}$ after hatching. Approximately $20 \%$ of the nerve cords were stained with the PAP method and the rest were stained with indirect fluorescence immunocytochemistry (FITC and/or TRITC). We observed neuron immunoreactivity in approximately $70 \%$ of the nerve cords. Within a given experiment, however, we had as high as a $50 \%$ failure rate, that consisted of either the complete absence 

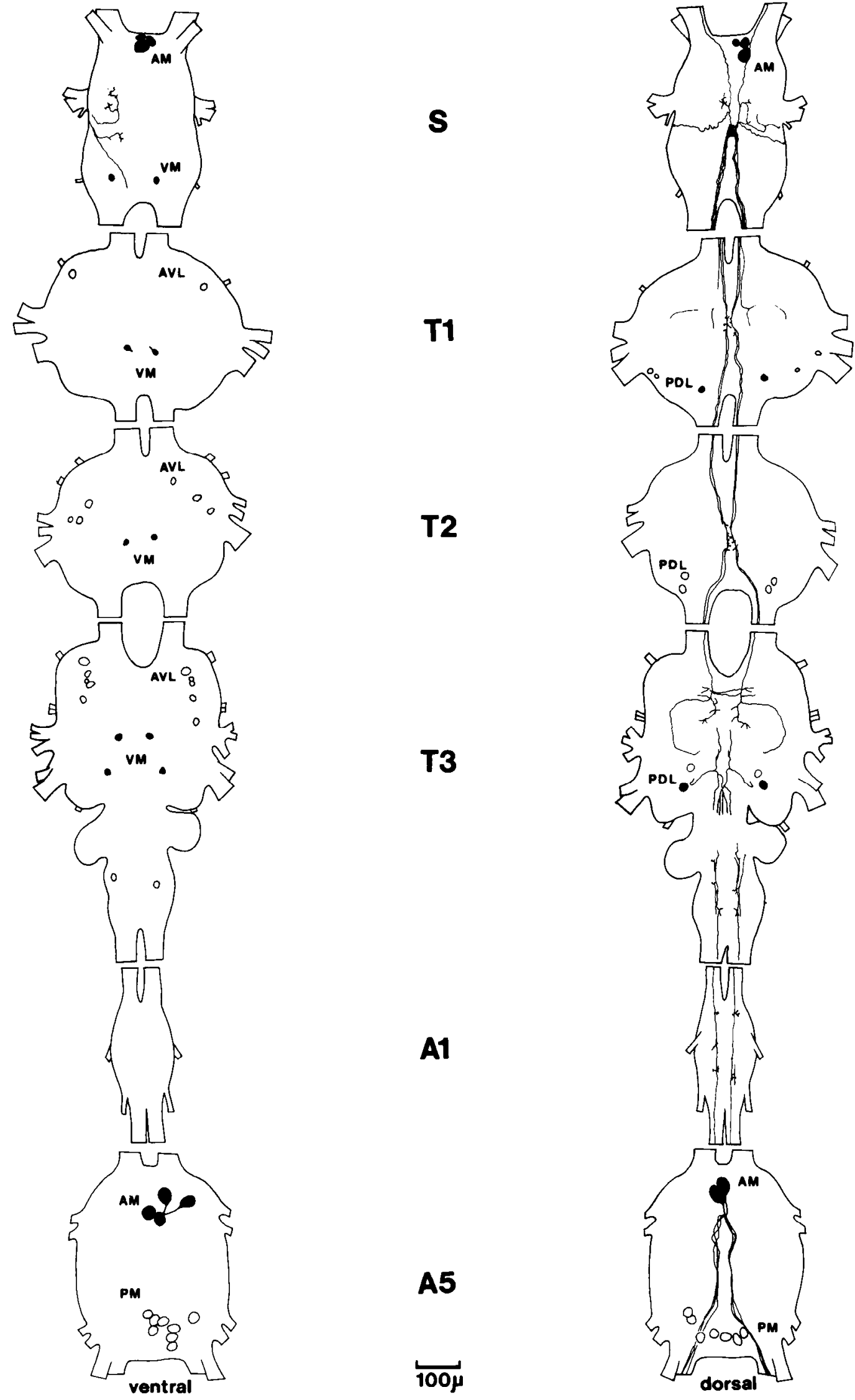

Figure 3. Proctolin-like immunocytochemistry in the ventral nerve cord about $48 \mathrm{hr}$ after hatching. This is a camera lucida drawing (with stylized nerve roots) from two individuals ( $S$ to $T 3 ; A 1$ and $A 5$ ) representative of the postembryonic immunoreactivity. Strongly stained somata are drawn solid, moderately stained somata are drawn in outline, and neuropilar immunoreactivity is traced. PAP reaction. 

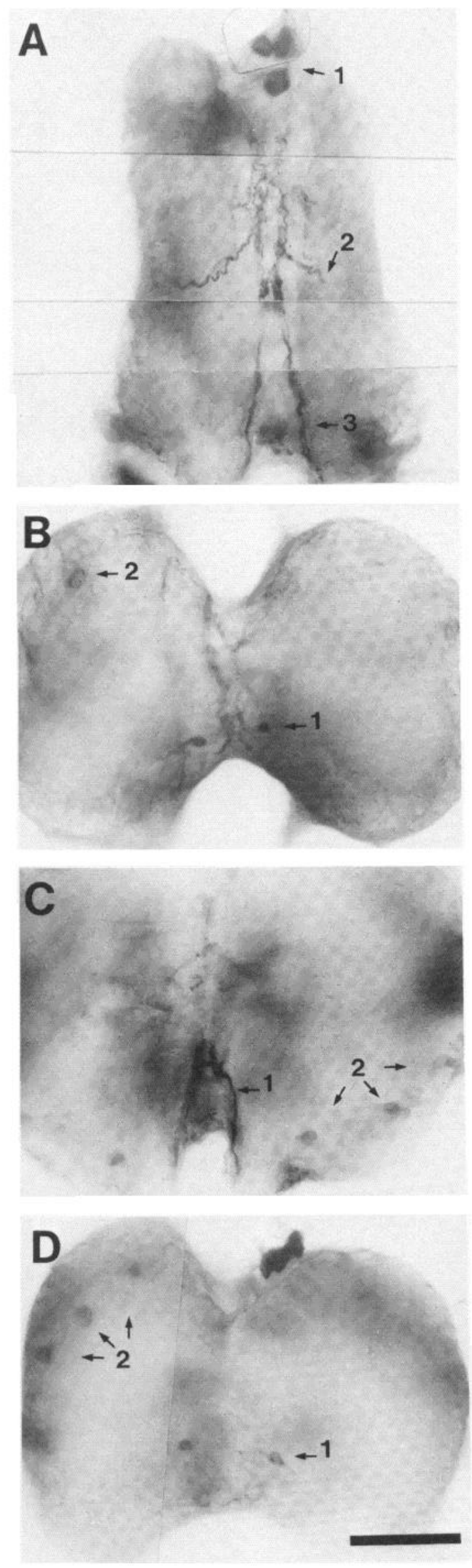

of staining or a high background staining which prevented us from seeing cells.

We examined all of the successfully stained nerve cords for the presence of potentially identifiable proctolinergic neurons. We looked for cells which stained repeatedly in the same positions within the ganglia. We also looked for bilaterally symmetrical somata, as well as constant immunoreactive arborizations, which are strong indicators of uniquely identifiable neurons in this system. We have limited our description to those cells which stained with an intensity well above background. These included cells of both strong and moderate immunoreactivity, as subjectively judged by us.

There were also some neurons that were observed in only a fraction of the nerve cords. We have included these cells in the description because, when present, they were observed in constant positions, often with bilateral symmetry. The variably staining cells will be noted in the text and figures where they occur. In this description we have excluded the few examples of cells that stained inconsistently and capriciously.

Figure 3 and Table I summarize the distribution of proctolinimmunoreactive neurons in the ventral nerve cord of the first instar grasshopper. Figure 3 is a drawing made from two nerve cords that were selected to represent the overall, consistent pattern of proctolinlike immunoreactivity (PLI). In addition to the neurons that consistently stain, there are a few illustrated in the map that belong to the class of variably staining neurons. These will be noted in the following description of proctolin-staining cells.

Subesophageal ganglion. A strongly staining cluster of large (15 to $30 \mu \mathrm{m}$ ) anterior-medial (AM) neurons lies in the crotch of the anterior connectives (Fig. 3, ganglion labeled $S$, dorsal and ventral aspects, and Fig. $4 A$, arrow 1 ). Neurites from these cells project into the anterior connectives into the brain. There is also a pair of strongly staining ventral-medial (VM) neurons, located posteriorly in the ganglion at the level of the labial nerve (Fig. 3, S, ventral).

There is strong neuropilar staining in the ganglion. At least three fibers from the two posterior connectives converge on the midline at the level of the maxillary nerve (Fig. 3, S, dorsal, and Fig. $4 A$, arrow 3 ). There they make fine blebbed branches to form a small knot of immunoreactive neuropil. From this region of dense arbor, transversely directed processes emerge projecting around the edge of the ganglion to the ventral side (Fig. $3, S$, dorsal and ventral, and Fig. $4 A$, arrow 2). Also, at least one axon on each side emerges from the knot and exits the ganglion in the anterior connectives (Fig. $3, S$, dorsal).

Thoracic ganglia: Cell body staining. During embryogenesis the prothoracic (T1) and mesothoracic (T2) ganglia arise from one embryonic segment each. These two ganglia share many anatomical features. We find that the pattern of cell staining is also similar in these ganglia. The metathoracic (T3) ganglion is formed from four segments: the metathoracic segment and the first three embryonic abdominal segments (reviewed in Bate, 1976). There are also features of the proctolin staining in this ganglion which resemble those seen in the other two thoracic ganglia.

Single bilaterally symmetrical pairs of VM neurons stain in both the prothoracic and mesothoracic ganglia. The VM neurons stain strongly, possess 10 - to $15-\mu \mathrm{m}$ cell bodies, and are positioned in

Figure 4. Proctolin immunocytochemistry in the subesophageal $(A)$, prothoracic $(B$ and $C)$, and mesothoracic ganglia $(D)$. $A$, Subesophageal ganglion, dorsal view, showing cell bodies lying between the anterior connectives (arrow 1), laterally directed axons that project circumferentially to the ventral side (arrow 2), and interganglionic axons entering the ganglion from the prothoracic ganglion (arrow 3). B, Prothoracic ganglion, ventral view, showing the pair of VM neurons (arrow 1 ) and the bilaterally symmetrical AVL neuron (arrow 2). C, Dorsal aspect of the prothoracic ganglion, showing interganglionic axons projecting to medial neuropil (arrow 1) and the PDL neuron (arrow 2). $D$, Mesothoracic ganglion, ventral view, showing the VM neuron pair (arrow 1) and three AVL neurons (arrows 2). Refer to Figure 8 for dorsal mesothoracic immunoreactivity. PAP reaction. Scale bar $=100$ $\mu \mathrm{m}$. 

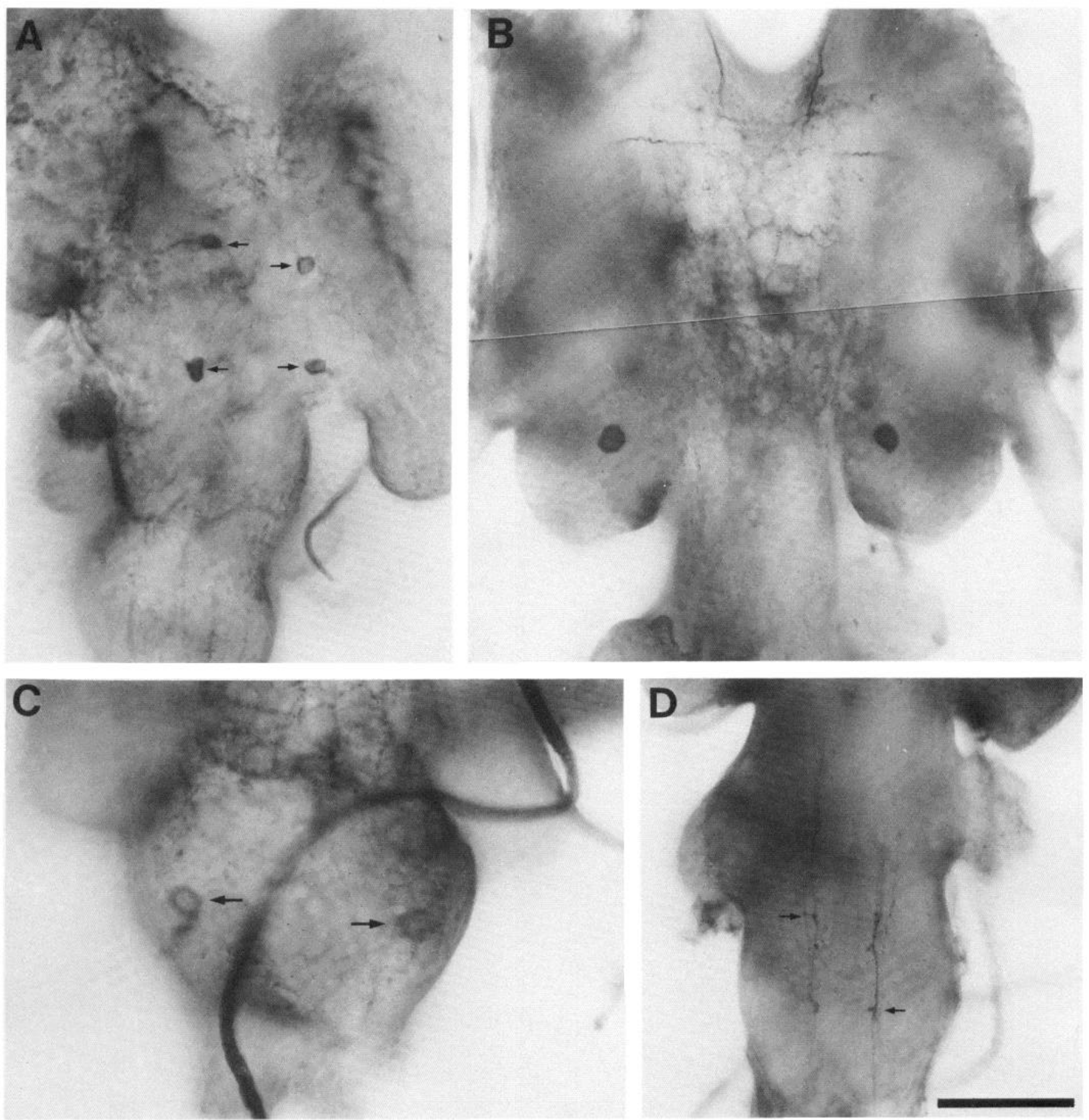

Figure 5. Metathoracic ganglion proctolin-like immunoreactivity. $A$, Ventral view of the ganglion illustrating the anterior and posterior VM interneuron pairs (arrows). B, Dorsal view of the same ganglion, with the two PDL neurons. $C$, Ventral staining of the third abdominal segment of the metathoracic ganglion, showing the VM neurons (arrows). $D$, Dorsal view of $C$ with proctolin-staining axons and possible terminals (arrows). PAP reaction. Scales: $A$ and $B=100$ $\mu \mathrm{m} ; C$ and $D=63 \mu \mathrm{m}$.

both ganglia at the level of nerve 5 (Figs. 3, T1 and T2 ventral, and $4, B$ and $D$, arrow 1). The proctolin-like staining of the prothoracic and mesothoracic VM pairs usually was limited to the cell bodies, although a short ( $<1$ cell diameter) portion of their neurites was occasionally revealed (Fig. $4 B$, left cell).

In the metathoracic ganglion there are two large, strongly immunoreactive pairs of VM neurons, with $15-$ to $25-\mu \mathrm{m}$ somata, located at the level of nerves 3 and 5 (Fig. 3, T3 ventral). The cell bodies form a conspicuous quartet on the ventral side of the ganglion (Fig. $5 A$, arrows). A second lightly stained cell body is occasionally detected within 2 cell body diameters of each VM neuron. The arborizations of the additional variably appearing neurons were not revealed. The two regularly appearing VM neuron pairs were often stained with a substantial portion of their neuropilar arbors (e.g., Fig. $6, B$ and $G$ ). In several preparations these could be reconstructed to at least third-order branching (Figs. $6 B$ and 7 ). The range of observed staining in these cells extends from a complete absence of arborization (about $50 \%$ ) to the fairly complete patterns illustrated in Fig. 7 (about 10 to $20 \%$ ), with partial arborizations making up the balance. The anterior and posterior VM morphologies are significantly different. 

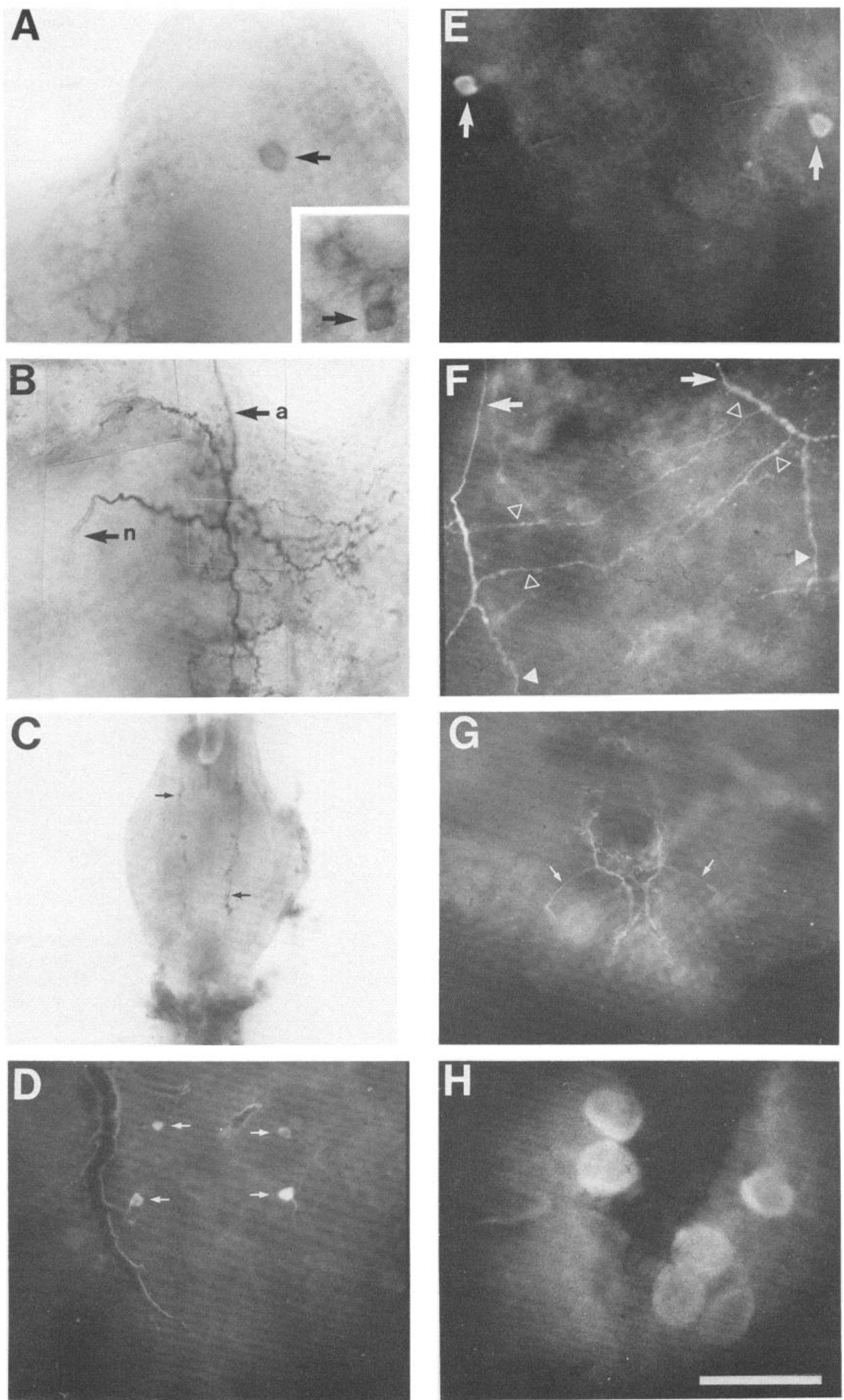
The anterior VM neuron projects its neurite in a 300 - to $400-\mu \mathrm{m}$ long, anteriorly directed arc. The projection originates near the ventral surface at the level of nerve 3 . Its dendritic arbor, with several large branches, lies on the opposite side, within dorsal-medial neuropil (Figs. 3, T3 dorsal, 6B, and 7, top two drawings). Up to two medially directed processes cross the midline and overlap with their contralateral homologues (Fig. 6F, open arrowheads). Most of the neuron's ganglionic arborization is directed posteriorly to the level of the cell body (Figs. $6 B$ and 7 ). The axon of the VM neuron projects anteriorly in the ipsilateral connective, where it contributes to a dense proctolinstaining knot (see Fig. 8 and below). The anterior VM neurons of the metathoracic ganglion are probably interganglionic proctolinergic interneurons.

The posterior VM neurons, by contrast, are confined to the metathoracic ganglion (Fig. 3, T3 dorsal, 6G, and 7, lower drawings). The arborization is less extensive and is directed posteriorly. The posterior VM's neurite emerges laterally (Fig. 7), then turns and dives dorsally for about $100 \mu \mathrm{m}$ into medial ipsilateral neuropil, dividing into anterior and posterior branches. The anterior branch stays ipsilateral and ascends to the level of nerve 3 . The posterior branch forks, with a medial branch crossing the midline to overlap with its contralateral partner (Figs. $6 G$ and 7). The posterior branch ends within the second abdominal contribution to the metathoracic ganglion. Thus, the posterior VMs are probably intraganglionic proctolinergic interneurons.

We have compared the reconstructed anatomy of a number of VM cells. Tracings of six metathoracic VM neurons from four hatchlings are shown in Figure 7. We conclude that the anterior and posterior VM cells are probably unique, identifiable neurons in which somatic position, peptidergic expression, and ganglionic arborization are conserved in conspecifics. To our knowledge these are the first uniquely identifiable peptidergic interneurons to be described in insects.

An additional moderately intense VM pair, with $15-\mu \mathrm{m}$ somata, is observed within the third abdominal segment contribution to the metathoracic ganglion (Figs. 3, T3 ventral, and 5C, arrows). We do not see arborizations from these somata, but there is neuropilar staining not associated with cell bodies in this region of the ganglion (Figs. 3, T3 dorsal, and 5D, arrow).

A second class of segmentally repeated proctolin-positive neurons are the anterior ventral-lateral or AVL neurons. These cells have moderately intense staining, $15-$ to $25-\mu \mathrm{m}$ somata, and are found in each thoracic ganglion (Fig. 3, $T 1$ to $T 3$ ventral).

In the prothoracic ganglion there is a single pair of AVL neurons (Fig. $4 B$, arrow 2). In the mesothoracic ganglion there are at least three such pairs (Fig. 4D, arrow 2). The population of AVL neurons in the metathoracic ganglion is the most variable. In addition to a single pair that usually stains (Fig. $6 A$ ), there may be as many as four more neurons on each side ( 5 pairs = about $1 / 5$ cases; examples illustrated in Fig. 3, T3 ventral, and Fig. 6A, inset).

In each ganglion the AVLs lie between the levels of nerves 1 and 3 , in areas known to be populated by thoracic motoneurons that exit nerves 3 and 5 (Bentley, 1970; Burrows and Hoyle, 1973; Wilson, 1979). The AVL neurons are good candidates for peptidergic skeletal motoneurons. The targets of the AVLs remain to be identi- fied. However, in the metathorax, one of them may be the slow motoneuron to the extensor tibiae muscle of the leg, SETi. (Burrows and Hoyle, 1973; Wilson, 1979; see "Discussion").

The third group of prominent proctolin-staining neurons is in the posterior dorsal-lateral regions of each of the thoracic ganglia, these are termed the PDL neurons (Fig. 3, T1 to T3, dorsal).

In the prothoracic ganglion there are three pairs of bilaterally symmetrical PDL neurons, with $15-\mu \mathrm{m}$ somata, that lie on the lateral edge of the ganglion, spaced between the posterior connectives and the root of nerve 5 (Figs. 3, $T 1$ dorsal, and $4 C$, arrow 2). In the mesothoracic ganglion there are two pairs of moderately staining PDL neurons adjacent to the posterior connectives (Fig. 3, T2 dorsal). We did not reconstruct the PDLs, although there is extensive neuropilar proctolin staining in their vicinity (see below).

In the metathoracic ganglion there are two large pairs of PDL neurons, with $25-$ to $35-\mu \mathrm{m}$ somata, located at the level of the 5 th nerve (Figs. 3, T3 dorsal, and $5 B$ ). The posterior pair has invariant intense immunoreactivity, whereas the other pair reacts variably and is absent from half of the samples.

The location and appearance of the posterior PDL neuron are strikingly similar to those of the identified proctolinergic slow coxal depressor or Ds motoneuron of the cockroach P. americana (Bishop and O'Shea, 1982b; Adams and O'Shea, 1983). The PDL neurons of the grasshopper may also be efferent, as they lie in the same region of the ganglion as do motoneurons whose axons exit nerves 4 and 6 . In the cockroach, the Ds motoneuron axon exits nerve 5 , but in the grasshopper there are no nerve 5 motoneuron cell bodies in this region. Furthermore, in favorable preparations, we observed a neurite of up to $100 \mu \mathrm{m}$ in length emerging from the posterior PDL pair that projects toward the midline, unlike Ds.

Thoracic ganglia: Neuropilar staining. The mesothoracic and prothoracic ganglia share similar neuropilar immunoreactivity, from the local arborizations of two to three transganglionic axons (Figs. $3, T 1$ and $T 2$, dorsal, $4 C$, arrow 1 , and 8 ). One of these axons on each side is from the anterior VM neurons of the metathoracic ganglion. A second, unidentified axon runs parallel to it from the metathoracic ganglion. On entering the mesothoracic ganglion, the axons establish a dense, tufted knot of fine processes, illustrated in Figure 8 . The numerous blebs and varicosities on the axonal projections suggest synapses. The two axons emerge from the knot and project anteriorly into the prothoracic ganglion, where the pattern is repeated (Fig. 3, $T 7$ dorsal). In the prothoracic ganglion we often observed a third axon joining the two derived from the knot. In a few cases (about $10 \%$ ) we could trace a partial neuropilar arbor, as is shown in Figure 3, $T 1$ dorsal.

Abdominal ganglia. In the grasshopper there are five abdominal ganglia. The first four abdominal ganglia are unfused, derived from the 4th to 7th embryonic segments. The fifth, compound terminal abdominal ganglion lies at the caudal end of the nerve cord and is derived from the 8 th to 11 th embryonic segments.

There is no reliable cell body staining in the four unfused abdominal ganglia. These ganglia have a dull immunofluorescence or background staining similar to that seen with blocked control antiserum. In fewer than $10 \%$ of the nerve cords we found one or two posterior-ventral staining cell bodies in the fourth unfused abdominal

Figure 6. Details of veritral nerve cord staining, and comparisons of early and late postembryonic stages. $A$, An AVL neuron in the region of the nerve 3 and nerve 5 motoneurons of the metathoracic (T3) ganglion. Inset: Ganglion with four staining AVL neurons in the same region. These cells may be motoneurons, including the cell SETi. First instar stage, 24 to $28 \mathrm{hr}$ postembryonic. $B$, Montage of the arborization of the anterior metathoracic VM interneuron. $a$, intersegmental axon; $n$, neurite (the cell body is not in focus). First instar. $C$. Proctolin staining in the first unfused abdominal ganglion (A1). Axons with blebbed processes are shown by arrows. First instar, dorsal view. $D$, Ventral view of the metathoracic ganglion in a late postembryonic individual, illustrating the anterior and posterior VM interneurons (arrows). Sixth instar female, indirect FITC. $E$, PDL neurons of the late postembryonic (sixth instar female) metathoracic ganglion, indirect FITC. F. Detail of the dendritic arbor of the anterior VM interneurons in a late postembryonic (sixth instar) metathoracic ganglion. The large arrows indicate the interganglionic axons that project into the mesothoracic ganglion. The solid arrowheads are contacting the posteriorly directed dendrites. The four open arrowheads are contacting the two pairs of medially directed dendrites, which overlap at the midline. Indirect FITC. $G$, Dorsal view of the metathoracic ganglion illustrating the overlapping arborizations of the posterior VM interneurons. The neurites are shown by arrows and the cell bodies are out of focus. First instar, indirect FITC. $H$, Ventral view of the AM cluster of the terminal ganglion in a late postembryonic individual. All six efferent somata are present on the ventral surface in this example. Compare to Figure $9 C$. Sixth instar female, indirect FITC. Scales: $A, B$ and $H=63$ $\mu \mathrm{m} ; C$ and $G=100 \mu \mathrm{m} ; D, E$, and $F,=250 \mu \mathrm{m}$. 


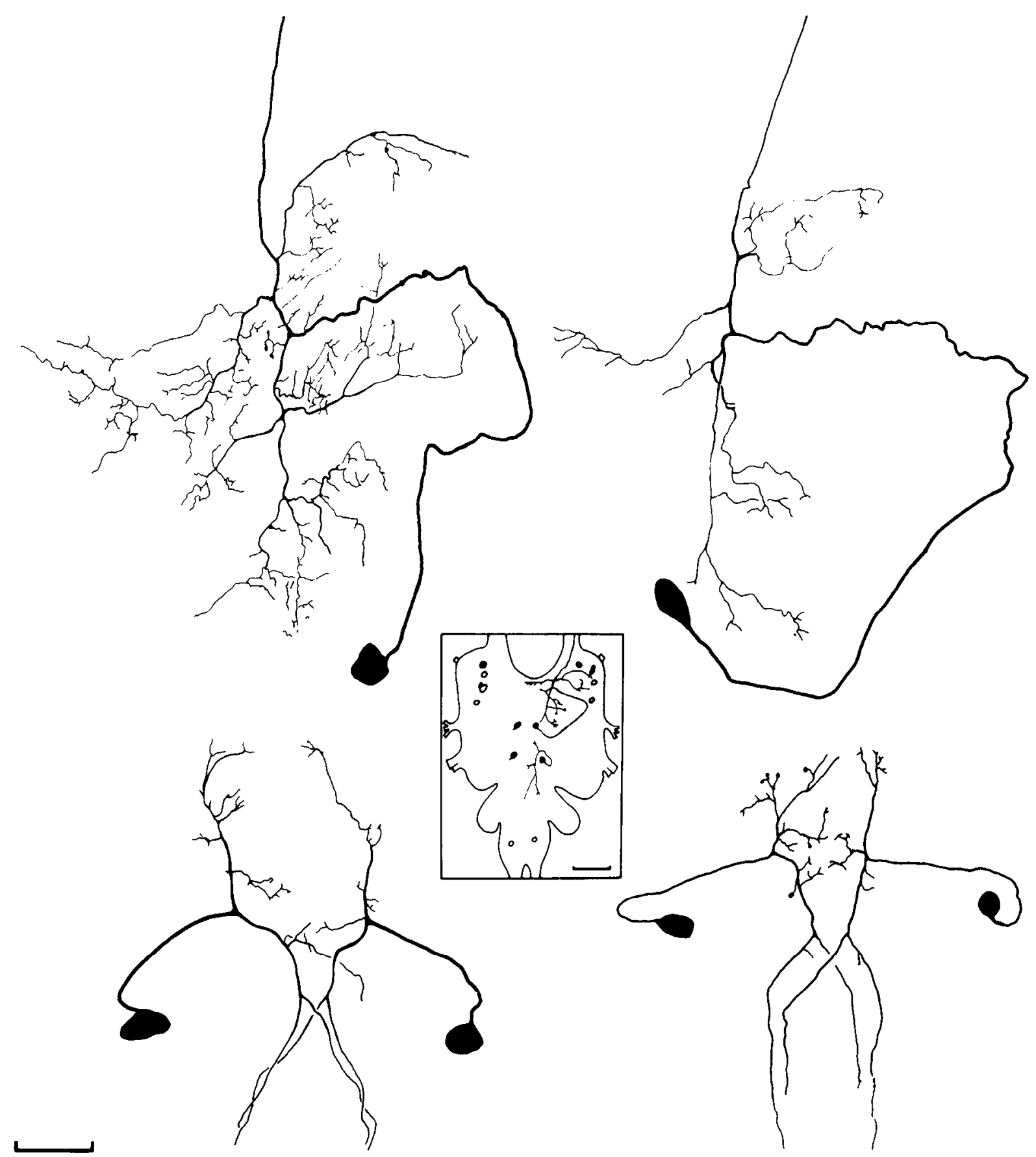

Figure 7. Camera lucida drawings of the two VM interneurons of the metathoracic ganglion. The upper two drawings are two examples of the anterior VM interneurons. The lower two drawings are two examples of both members of the paired posterior VM interneurons. Note the similar arborizations of the two examples, which show differing extent of immunoreactivity. The inset shows the location of these cells within the hatchling metathoracic ganglion. PAP reaction, first instar. Scale $=50 \mu \mathrm{m}$; inset scale $=100 \mu \mathrm{m}$.

ganglion. There is, however, neuropilar staining in all four unfused abdominal ganglia. The proctolin immunoreactivity consists of one or two fine transganglionic axons, extending up and down each connective, which sprout a few short, blebbed processes within the dorsal neuropil of each ganglion (Figs. 3, A1, dorsal, and 6C).

In the fifth abdominal ganglion there is consistent and strong cell body and neuropilar staining. Cell body staining is confined to two clusters of neurons. The anterior-medial (AM) cluster is composed of six large ( 25 to $40 \mu \mathrm{m}$ ), strongly staining neurons located at the level of the 8 th nerve roots. The posterior-medial (PM) cluster is composed of from 14 to 16 somewhat smaller (15 to $25 \mu \mathrm{m})$, moderately staining neurons (Fig. $3, A 5$ ). The PM cluster lies in the crotch between the two compound cercal roots at the level of the 9 th and 10 th nerves. The cell bodies are distributed from the ventral to the dorsal side of the ganglion. Staining in the PM neurons arises after hatching and is complete by about $24 \mathrm{hr}$ post-hatching (Keshishian and O'Shea, 1985).

The cell bodies of the AM cell cluster are distributed in three patterns (Fig. 9). In about one-fourth of the nerve cords examined, four cell bodies are found on the ventral side of the ganglion, opposite to the remaining two dorsal AM cells. This pattern of 4 ventral +2 dorsal cells is illustrated in Figs. $3, A 5$, and $9, A$ and $A^{\prime}$. In an additional fourth of the observed ganglia there are 5 ventral cells +1 dorsal $A M$ cell body (Fig. $9, B$ and $B^{\prime}$ ). Finally, in about 


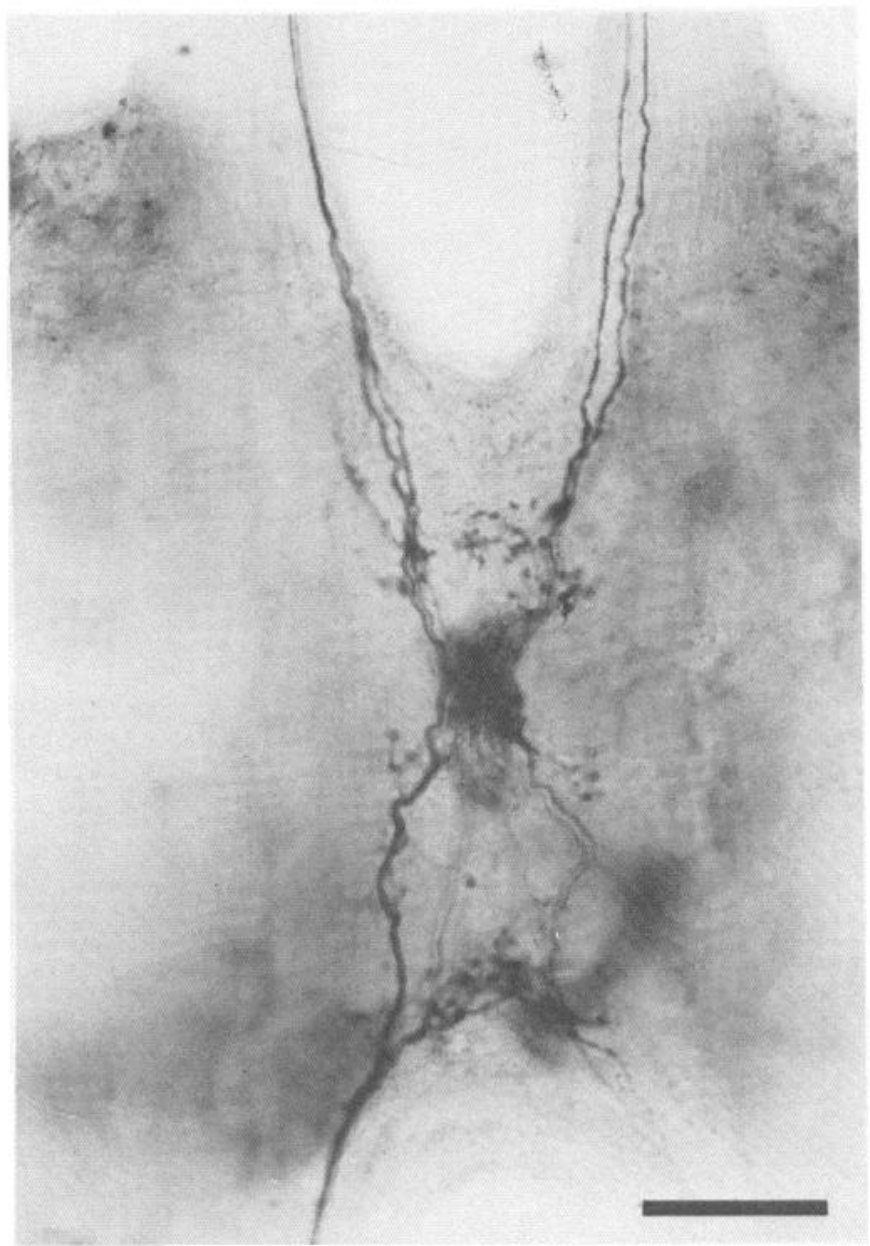

Figure 8. The dense, knot-like, neuropilar proctolin staining seen in a dorsal view of the mesothoracic ganglion. At least two transganglionic axons with proctolin-like immunoreactivity enter and exit this ganglion on each side. The axons converge onto median neuropil and sprout profusely with fine varicose processes, suggestive of synaptic endings. One axon on each side can be traced back to the two anterior VM interneurons of the metathoracic ganglion. A similar neuropilar immunoreactivity is found in the prothoracic ganglion. First instar, PAP demonstration. Scale bar $=50 \mu \mathrm{m}$.

half of the ganglia there are six ventral AM cell bodies, with no cells on the dorsal side (Fig. 9, $C$ and $C^{\prime}$ ).

The number of AM cells and the relative frequencies of the three patterns are stereotyped and are independent of either sex or developmental stage. We have observed a single case (about $1 \%$ of the total sample) of seven cells in the AM cluster, with a 5 ventral +2 dorsal pattern. In $5 \%$ of the ganglia we have observed only five cells, with $3+2,4+1$, and $5+0$ (ventral + dorsal) patterns.

The six neurons of the AM cluster are efferent; in favorable preparations the axons of these cells can be traced (Fig. 3, A5 dorsal; see also Keshishian and O'Shea, 1985). The neurites converge into a single bundle in the eighth abdominal segment neuropil but soon diverge and run posteriorly on either side of the ganglion. There is a single axon for each cell body, with three axons on each side. The axons exit the ganglion medially within the cercal nerves. Members of the AM cluster project to the intrinsic muscles of the hindgut via the rectal branch of the cercal nerve (Keshishian and O'Shea, 1985)

Developmental stability of the pattern. Is this description of proctolin-staining neurons in the newly hatched animal representative of the pattern found in later stages of postembryonic development, or is there a major rearrangement in either the number or form of the cells we have described? We examined the proctolin staining in nerve cords of animals at the last stage of development before adulthood (sixth instar females). There were no significant differences seen in the PLI in animals at the beginning and end of postembryonic development. For example, in the metathoracic ganglion, the staining immediately before adulthood consists of the same groups of neurons found in the ganglion at the end of embryogenesis. These cells include the quartet of ventral medial VM cells (Fig. 6D) and the conspicuous PDL neurons on the posterior dorsal side (Fig. $6 E$ ). The neuroanatomy of proctolin-staining cells is also stable, as is seen in the detail of the dendritic arborizations of the anterior VM neurons (Fig. 6F). Cell numbers within clusters of neurons are also stable, as is shown in Figure $6 \mathrm{H}$, where the usual number of six AM cells is seen in a sixth instar terminal ganglion. We conclude, therefore, that the map of proctolin expression within the CNS is not extensively altered during postembryonic life. The onset and expression of the neurotransmitter proctolin in the mature nervous system are therefore the product of developmental events that occur during embryogenesis.

\section{Discussion}

We have presented chromatographic evidence for the presence of a proctolin-like substance in the CNS of the grasshopper Schistocerca nitens. Using immunocytochemistry, we have surveyed the nervous system at the end of embryogenesis and mapped the cell body locations of more than 70 probably proctolinergic neurons. We find that a stable map of neurons expressing this neurotransmitter phenotype is largely established by the end of embryogenesis and is not altered significantly during postembryonic life. We have characterized several neurons that appear to be uniquely identifiable, among which are both interneurons and skeletal motoneurons.

Is the pentapeptide proctolin present in the grasshopper nervous system, and is it responsible for the immunoreactivity of the neurons described in this study? Although we have not sequenced the bioactive peptide isolated from the grasshopper CNS, we think that our evidence for its being proctolin is strong. The substance coelutes with the authentic pentapeptide in a stringent reverse phase HPLC system and shares with it identical quantitative and qualitative effects upon the proctolin-sensitive muscle. We believe it is unlikely that a molecule other than proctolin is responsible for these observations. Although immunoreactivity could be due to cross-reaction with substances other than proctolin, we think that the proctolin staining is due to the presence of authentic proctolin in the neurons. This is suggested by the correlation on a ganglion-by-ganglion basis of the observed numbers of staining cells with the measured levels of bioassayed proctolin (e.g., Fig. 2).

Most neuronal identifications and neuronal maps in invertebrate nervous systems have been based upon physiological and/or morphological criteria. We at present know relatively little about the chemical identity and cellular distribution of neurotransmitters in the insect CNS. In general, therefore, we cannot assign a neurotransmitter identity to the neurons identified on physiological and morphological grounds. There are, however, a few neurochemical mapping studies in the grasshopper. For example, in the metathoracic ganglion, octopamine has been found in the dorsal unpaired medial (DUM) neurons (Evans and O'Shea, 1978) and is known to be the transmitter of a uniquely identified member of this group of cells (the efferent neuron DUMETi; O'Shea and Evans, 1979). An unknown but high percentage of the DUM cells of each segment are also thought to express this transmitter (Goodman et al., 1979). Serotonin has also been mapped in the nerve cord of adults and embryos of the grasshopper, and Taghert and Goodman (1984) and Taghert et al. (1984) have described a number of uniquely identifiable neurons that stain for this transmitter.

Our description of PLI in the CNS is intended to serve as a guide for identifying proctolinergic neurons in this organism. We adopted strict criteria for including neurons in the map. Only those cells that stain with at least moderate intensity, appear consistently, and in some cases have demonstrable arborizations are included. It is 

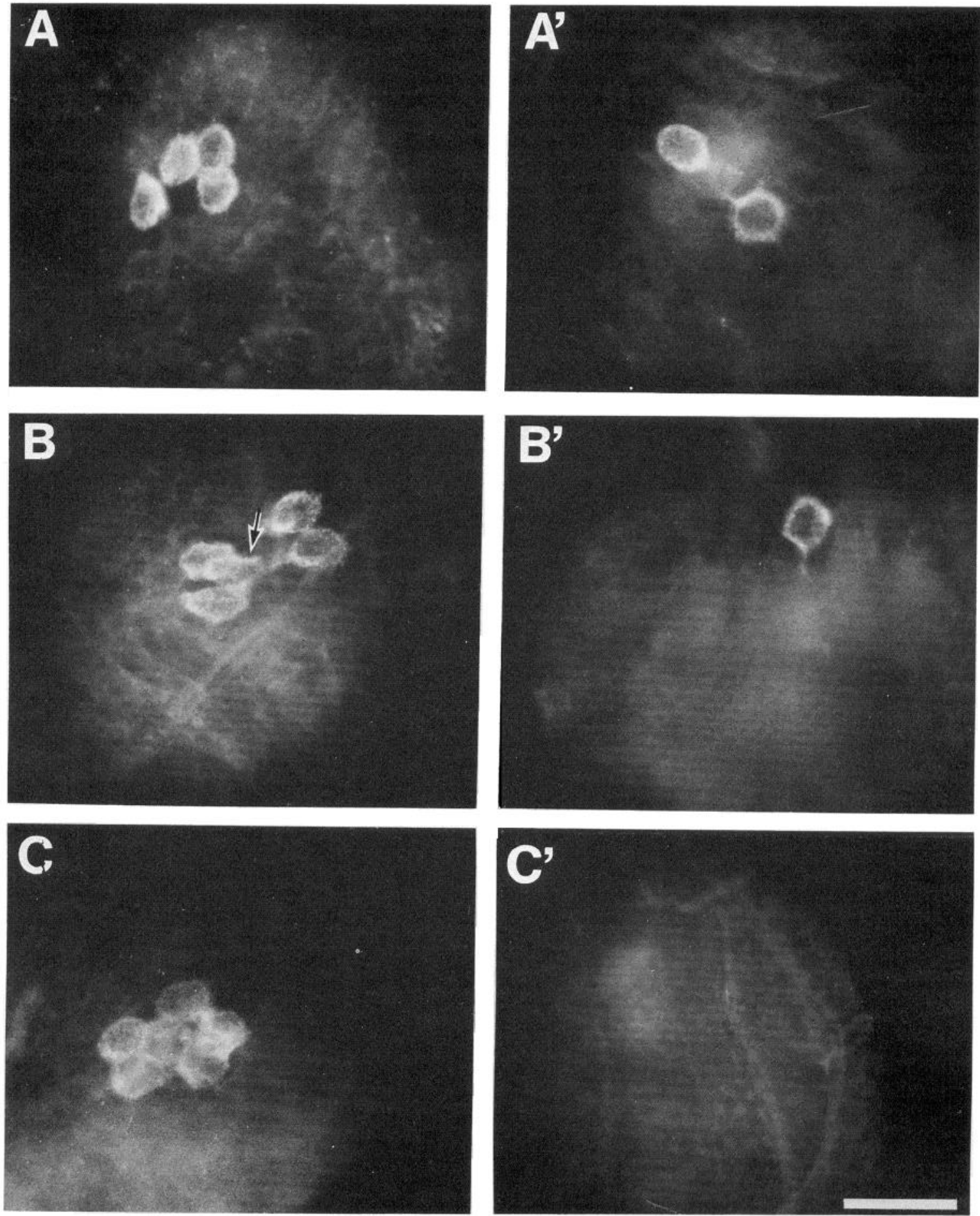

Figure 9. The AM cluster of the terminal ganglion is composed of six efferent neurons (see Fig. 3) whose cell bodies are distributed in one of three patterns. $A$, In approximately one-fourth of the nerve cords examined, four of the cells are found on the ventral side of the ganglion, with the remaining two dorsal $\left(A^{\prime}\right)$. $B$, In an additional fourth of the ganglia there are five ventral and a single dorsal cell $\left(B^{\prime}\right)$. The fifth cell is indicated by the arrow. $C$, In the remaining half of the ganglion all six AM cells are located on the ventral side $(C)$, with no cells visible on the dorsal side $\left(C^{\prime}\right)$. Indirect FITC immunofluorescence, $100 \%$ stage embryos. Scale bar $=50 \mu \mathrm{m}$.

probable, therefore, that some proctolin-containing neurons in the CNS were excluded.

We draw the following generalizations from the pattern of proctolin staining. The number of proctolin-like immunoreactive cells (about 70) represents less than $0.6 \%$ of our estimate of about 12,000 neurons of the ventral nerve cord. Although this proportion may seem small, it is actually in line with the proportions of cells containing other known transmitters or neuroactive substances in this and related species. In the grasshopper the proportion containing octopamine (Goodman et al., 1979), serotonin (Taghert and Goodman, 1984; Taghert et al., 1984), or adipokinetic hormone (Schooneveld et al., 1985) each comprises less than $2 \%$ of the total. In the cockroach a similarly low proportion is found for cells staining for proctolin (Bishop and O'Shea, 1982a) or serotonin (Bishop and 
O'Shea, 1982b), or the newly discovered peptides $\mathrm{Ml}$ and $\mathrm{MII}$ (O'Shea et al., 1984; Witten et al., 1984). This strongly suggests that the total number of neurotransmitters in invertebrates is potentially high. Supporting this idea is the proliferation of newly discovered invertebrate neurotransmitters, especially neuropeptides (O'Shea and Schaffer, 1985).

Proctolin staining in the grasshopper is not restricted to a single type of CNS neuron but is found in both interneurons as well as motoneurons. Our finding that interneurons can have immunoreactivity is the first report of uniquely identified interneurons with PLI in arthropods. The presence of proctolin in functionally heterogeneous neurons suggests that it may have diverse roles in the behavior of this organism. At present, the only functions that have been assigned to this peptide in insects are concerned with the control of cardiac, gut, and skeletal muscles. The evidence presented in this paper, that interneurons can have proctolin, implies that the neuropeptide is also active upon neuronal targets within the CNS. Possible sites for the release of proctolin in the CNS are the dense "knots" of immunoreactive neuropil found in the subesophageal, prothoracic, and mesothoracic ganglia, where blebs and varicosities that could represent release sites are found in abundance (see Fig. 8 for example)

Similar patterns of staining of both cell body and neuropil are repeated in the thoracic segments. The iterated staining cell bodies may be segmentally homologous neurons. There is good evidence in grasshopper for the segmental repetition of neurons in these ganglia, extending to their morphology, physiology, and, in the case of the DUM cell cluster, neurotransmitter type (Goodman et al., 1979; Wilson, 1979). Ganglionic neurons are largely derived from a segmentally repeated pattern of bilaterally symmetrical precursor neuroblasts. Segmentally homologous precursor cells can produce segmentally homologous neurons (Goodman and Spitzer, 1979; Goodman et al., 1979), and this may ultimately account for the segmental features of proctolin staining

Many of the cells in our map have not been described previously, but a few seem to correspond to neurons that have been identified on physiological and morphological criteria in this animal. Additional cells stained in this study appear to be homologous to proctolinstaining neurons described in the cockroach. There is good evidence that one of the AVL neurons in the metathoracic ganglion is the slow motoneuron to the extensor tibiae muscle of the leg, SETi. This conclusion is based on the location of the cell body, together with the reported presence of proctolin-staining motor endings on the extensor tibiae muscle (J. Witten, M. K. Worden, M. Schaffer, and M. O'Shea, manuscript in preparation). The three other motoneurons that innervate the extensor tibiae muscle (the fast extensor, FETI, the octopaminergic cell, DUMETi, and the common inhibitor, Cl) do not stain in the CNS and can be ruled out as sources of the muscle staining (see "Results"). Furthermore, regions of the extensor tibiae muscle innervated by SETi respond to local application of proctolin in a manner that is physiologically similar to the stimulation of SETi (Witten et al., 1984).

Proctolin immunoreactivity has been mapped in the cockroach by Bishop and O'Shea (1982a). We have identified possible interspecies staining homologies between cockroach and grasshopper. Periplaneta has a pair of VM neurons staining in the pro- and mesothoracic ganglia, as does Schistocerca, and the proctolinergic cockroach Ds motoneurons of the metathoracic ganglion lie in the same posterior dorsal-lateral region as the PDL neurons of the grasshopper. The differences between cockroach and grasshopper staining are, nevertheless, significant. For example, there are about 4 times as many staining cells in cockroach, as well as more than 4 times as much proctolin. Staining cells in Periplaneta are also found in the unfused abdominal ganglia, where there was no evidence of cell body staining and relatively little proctolin in Schistocerca.

In conclusion, we have elucidated at the cellular level the pattern of expression of a neuropeptide transmitter in an organism in which both functional and developmental questions can be studied directly at the level of single identified cells. As a prelude to pursuing the developmental questions, we have studied the acquisition and expression of this phenotype in the course of embryogenesis. This is the subject of the following paper (Keshishian and O'Shea, 1985).

\section{REFERENCES}

Adams, M. E., and M. O'Shea (1983) Peptide cotransmitter at a neuromuscular junction. Science 221: 286-289.

Bate, C. M. (1976) Embryogenesis of an insect nervous system. I. A map of the thoracic and abdominal neuroblasts in Locusta migratoria. J. Embryol. Exp. Morphol. 35: 107-123.

Bentley, D. (1970) A topological map of the locust flight system motor neurons. J. Insect. Physiol. 16: 905-918.

Bentley, D., and H. Keshishian (1982) Pathfinding by peripheral pioneer neurons in the grasshopper. Science 218: 1082-1088.

Bishop, C. A., and M. O'Shea (1982a) Neuropeptide proctolin (H-Arg-TyrLeu-Pro-Thr-OH): Immunocytochemical mapping of neurons in the central nervous system of the cockroach. J. Comp. Neurol. 207: 223-238.

Bishop, C. A., and M. O'Shea (1982b) Serotonin immunoreactive neurons in the central nervous system of an insect (Periplaneta americana). J. Neurobiol. 14: 251-269.

Bishop, C. A., R. J. Miller, and M. O'Shea (1981) Neuropeptide proctolin (HArg-Tyr-Leu-Pro-Thr-OH): Immunological detection and neuronal localization in the insect central nervous system. Proc. Natl. Acad. Sci. U. S. A. 78: 5899-5902.

Bishop, C. A., J. J. Wine, and M. O'Shea (1984) Neuropeptide proctolin in postural motoneurons of the crayfish. J. Neurosci. 4: 2001-2009.

Brown, B. E. (1967) Neuromuscular transmitter substance in insect visceral muscle. Science 155: 595-597.

Brown, B. E. (1975) Proctolin: A peptide transmitter candidate in insects. Life Sci. 17: 1241-1252.

Brown, B. E. (1977) Occurence of proctolin in six orders of insects. J. Insect Physiol. 23: 861-864.

Brown, B. E., and A. N. Starratt (1975) Isolation of proctolin, a myotropic peptide from Periplaneta americana. J. Insect Physiol. 21: 1879-1881.

Burrows, M., and G. Hoyle (1973) Neural mechanisms underlying behavior in the locust Schistocerca gregaria. III. Topography of limb motoneurons in the metathoracic ganglion. J. Neurobiol. 4: 167-186.

Evans, P., and M. O'Shea (1978) The identification of an octopaminergic neurone and the modulation of a myogenic rhythm in the locust. J. Exp. Biol. 73: 235-260.

Giloh, H., and J. W. Sedat (1932) Fluorescence microscopy: Reduced photobleaching of rhodamine and fluorescein protein conjugates by $n$ propyl gallate. Science 217: 1252-1255.

Goodman, C. S., and N. C. Spitzer (1979) Embryonic development of identified neurones: Differentiation from neuroblast to neurone. Nature 280: 208-214.

Goodman, C. S., M. O'Shea, R. E. McCaman, and N. C. Spitzer (1979) Embryonic development of identified neurons: Temporal pattern of morphological and biochemical differentiation. Science 204: 1219-1222.

Goodman, C. E., M. Bate, and N. C. Spitzer (1981) Embryonic development of identified neurons: Origin and transformation of the $\mathrm{H}$ cell. J. Neurosci. 1: $94-102$

Goodman, C. S., M. J. Bastiani, C. Q. Doe, S. deLac, S. L. Helfand, J. Y Kuwada, and J. B. Thomas (1984) Cell recognition during neuronal development. Science 225: 1271-1279.

Holman, G. M. and B. J. Cook (1979) Evidence for proctolin and a second myotropic peptide in the cockroach Leucophaea maderae, determined by bioassay and HPLC analysis. Insect Biochem. 9: 149-154.

Keshishian $H$., and M. O'Shea (1985) The acquisition and expression of a peptidergic phenotype in the grasshopper embryo. J. Neurosci. 5: 10051015.

Kravitz, E. A., S. Glusman, R. M. Harris-Warrick, M. S. Livingstone, T. L. Schwarz, and M. F. Goy (1980) Amines and a peptide as neurohormones in lobster: Action on neuromuscular preparations and preliminary behavioral studies. J. Exp. Biol. 89: 159-175.

Lingle, C. J. (1979) The effects of acetylcholine, glutamate, and biogenic amines on muscle and neuromuscular transmission in the stomatogastric system of the spiny lobster, Panulirus interuptus. PhD. thesis, University of Oregon, Eugene.

Miller, M. W., and R. E. Sullivan (1981) Some effects of proctolin on the cardiac ganglion of the Maine lobster, Homarus americanus (Milne Edwards). J. Neurobiol. 12: 629-639.

O'Shea, M., and M. E. Adams (1981) Pentapeptide (proctolin) associated with an identified neuron. Science 213: 567-569. 
O'Shea, M., and C. A. Bishop (1982) Neuropeptide proctolin associated with an identified motoneuron. J. Neurosci. 2: 1242-1251.

O'Shea, M., and P. Evans (1979) Potentiation of neuromuscular transmition by an octopaminergic neuron in the locust. J. Exp. Biol. 79: 169-190.

O'Shea, M., and M. Schaffer (1985) Neuropeptide function: The invertebrate contribution. Annu. Rev. Neurosci., in press.

O'Shea, M., J. Witten, and M. Schaffer (1984) Isolation and characterization of two myoactive neuropeptides: Further evidence of an invertebrate family. J. Neurosci. 4: 521-529.

Pearson, K. G., and M. O'Shea (1985) Escape behavior in the locust: The jump and its initiation by visual stimuli. In Neural Basis of Startle Behavior, R. Eaton, ed., Plenum Press, New York, in press.

Schooneveld, H. M., H. M. Romberg-Privee, and J. A. Veenstra (1985) Adipokinetic hormone-immunoreactive peptide in the endocrine and central nervous system of several insect species: A comparative immunocytochemical approach. Gen. Comp. Endocrinol. 57: 184-194.

Schwarz, T. L., R. M. Harris-Warrick, S. Glusman, and E. A. Kravitz (1980) A peptide action in a lobster neuromuscular preparation. J. Neurobiol. 11: 623-628.
Schwarz, T. L., G. M. H. Lee, K. K. Siwicki, D. G. Standaert, and E. A. Kravitz (1984) Proctolin in the lobster: The distribution, release, and characterization of a likely neurohormone. J. Neurosci. 4: $\uparrow 300-1311$.

Starratt, A. N., and B. E. Brown (1975) Structure of the pentapeptide proctolin, a proposed neurotransmitter in insects. Life Sci. 17: 1253-1256.

Sullivan, R. E. (1979) A proctolin-like peptide in crab pericardial organs. J. Exp. Zool. 210: 543-552.

Taghert, P. H., and C. S. Goodman (1984) Cell determination and differentiation of identified serotonin-immunoreactive neurons in the grasshopper embryo. J. Neurosci. 4: 989-1000.

Taghert, P. H., C. Q. Doe, and C. S. Goodman (1984) Cell determination and regulation during development of neuroblasts and neurones in grasshopper embryos. Nature 307: 163-165.

Wilson, J. A. (1979) The structure and function of serially homologous leg motoneurons in the locust. I. Anatomy. J. Neurobiol. 10: 41-65.

Witten, J., M. K. Worden, M. Schaffer, and M. O'Shea (1984) New classification of insect motoneurons: Expression of different peptide transmitters. Soc. Neurosci. Abstr. 10: 151 